\title{
MICROPROPAGAÇÃO DA CANA-DE-AÇÚCAR
}

Emmerson Rodrigues de Moraes ${ }^{1,3}$, Ariel Santivañez Aguilar ${ }^{3}$, Daniel Lucas Magalhães Machado ${ }^{3}$, Antônio Marcos Diniz Campos ${ }^{3}$, Simone Abreu Asmar ${ }^{3}$, Jose Magno Queiroz Luz ${ }^{2}$

${ }^{1}$ Instituto Federal de Educação, Ciência e Tecnologia Goiano - Campus Morrinhos, Goiás, Brasil. e-mail: emmerson.moraes@ifgoiano.edu.br; ${ }^{2}$ Instituto de Ciências Agrárias, UFU, Av. Amazonas, s/n, 38400-902, Uberlândia, MG, Brasil. ${ }^{3}$ Programa de Pós-graduação em Agronomia, Universidade Federal de Uberlândia (UFU), Uberlândia, MG, Brasil

\section{RESUMO}

A cana-de-açúcar é cultivada em quase todas as regiões agrícolas brasileiras, sendo o Brasil o maior produtor mundial, o que demanda programas de melhoramento para que sejam criadas variedades mais produtivas e eficientes, adaptadas para cada região. Em programas de melhoramento genético da cana-de-açúcar há necessidade, sob determinadas circunstâncias, de se multiplicar o material selecionado com rapidez. Neste cenário, a micropropagação aparece como uma alternativa ao processo convencional de propagação vegetativa por meio de colmos. $O$ objetivo desta revisão foi descrever o cenário sobre pesquisas com micropropagação em cana- deaçúcar, como a cultura de meristemas, calos de cana-de-açúcar, embriogênse somática, conservação de germoplasma in vitro e criopreservação. Observou-se na literatura que há um amplo espectro de uso para os numerosos e bem estabelecidos protocolos para a manipulação in vitro de morfogênese em cana- de- açúcar. O prospecto de produzir novas características via indução da variação somaclonal e experimentação in vitro para tolerância a pragas e doenças não foi ainda amplamente explorado. Enquanto benefícios do crescimento mínimo são reconhecidos na conservação de germoplasmas in vitro de cultivares elite de cana de açúcar, e todo potencial positivo desta técnica e da criopreservação pode ainda ser expandida. Por outro lado, técnicas na produção em massa de genótipos superiores e livres de patógenos, já tem sido integrado em muitos programas de melhoramento de cana-de-açúcar.

Palavras-chave: Cultivo in vitro. Multiplicação. Propagação. Saccharum spp.

\section{MICROPROPAGATION OF SUGAR CANE}

\begin{abstract}
Sugarcane is cultivated in almost all Brazilian agricultural regions, Brazil being the world's largest producer, which requires breeding programs to create more productive and efficient varieties adapted to each region. In sugarcane breeding programs there is a need, under certain circumstances, to multiply the selected material rapidly. In this scenario, micropropagation appears as an alternative to the conventional process of vegetative propagation through stalks. The objective of this review was to describe the scenario on micropropagation research in sugarcane, such as meristem culture, sugarcane calli, somatic embryogenesis, in vitro germplasm conservation and cryopreservation. It has been observed in the literature that there is a wide spectrum of use for the numerous and well established protocols for the in vitro manipulation of sugarcane morphogenesis. The prospect of producing new features via induction of somaclonal variation and in vitro experimentation for pest and disease tolerance has not yet been extensively explored. While benefits of minimal growth are recognized in in vitro germplasm conservation of elite sugarcane cultivars, and all positive potential of this technique and cryopreservation may still
\end{abstract}


be expanded. On the other hand, techniques in the mass production of superior and pathogenfree genotypes have already been integrated in many sugarcane breeding programs.

Keywords: In vitro culture. Multiplication. Propagation. Saccharum spp.

\section{INTRODUÇÃO}

A cana-de-açúcar (Saccharum spp.) é cultivada em quase todas as regiões agrícolas brasileiras, com uma produção de 634.767 .000 toneladas, sendo o Brasil o maior produtor mundial com uma área colhida no 2014 de 9.887.251 hectares, sendo responsável por mais de um terço de toda produção, na safra 2014-2015, foram produzidos 28.659 .924 de litros de etanol e 35.560.200 toneladas de açúcar no Brasil (AGRIANUAL, 2016).

O Brasil é um país de grande diversidade de climas, o que demanda programas de melhoramento para que sejam criadas variedades mais produtivas e eficientes, adaptadas para cada região. A necessidade, agilidade e rapidez de multiplicação de material genético em cana-deaçúcar é necessária. A micropropagação de cana possibilita hoje sua clonagem comercial em biofábricas, por diferentes protocolos de micropropagação; semi-sólido (GARCIA et al., 2007), líquido estacionário e por imersão temporal (LORENZO et al., 2001; ARENCIBIA et al., 2008).

A eliminação de vírus de plantas de material propagativo tem sido obtida através de três métodos principais: termoterapia, quimioterapia e cultura de tecidos (GROUT, 1999). A cultura de tecidos da cana-de-açúcar tem sido utilizada pelos programas de melhoramento devido à redução no tempo de multiplicação de clones e de variedades promissoras, facilitando a rápida obtenção de grandes quantidades de material propagativo do genótipo de interesse, além da eliminação de um grande número de patógenos (HENDRE et al., 1983).

Dentre as técnicas de cultura de tecido, a utilização do processo de limpeza clonal a partir da cultura de meristemas não garante totalmente a sanidade do material trabalhado (TORRES et al., 1998), a contaminação microbiana é responsável por perdas severas em biofábricas e laboratórios de pesquisa (DONATO et al., 2005), sendo a contaminação por microrganismos é conhecida como um dos mais sérios problemas da cultura de tecidos de plantas, especialmente, em espécies tropicais (KNEIFEL; LEONHARDT, 1992).

\section{MICROPROPAGAÇÃO}

A micropropagação, entre as aplicações da cultura de tecidos vegetais, é a técnica de maior impacto e de resultados mais concretos (ANDRADE, 2002), engloba diferentes etapas que vão desde o estabelecimento da cultura in vitro até seu enraizamento, culminando com a aclimatização da microplanta (BASTOS et al., 2007). Esta técnica demanda condições de manuseio assépticas (SHARP et al., 1979), e ainda, a escolha de uma planta matriz de apropriada qualidade sanitária pode reduzir a contaminação.

A propagação in vitro, também chamada de micropropagação referindo-se ao tamanho dos propágulos utilizados, é a técnica que garante cultura de tecidos maior êxito e proporciona a obtenção de plantas sadias e produção a larga escala (THORPE, 2012). A propagação de plantas das diferentes variedades de cana de açúcar tem sido obtida rotineiramente através das técnicas de propagação in vitro (KAUR; SANDHU, 2015).

A produção de mudas propagadas garante características desejadas, utilização de pequenos espaços, e indivíduos livres de doenças ou vírus (SANTOS, 2011).

Vários países produtores de cana-de-açúcar utilizam a micropropagação em massa para multiplicar variedades de interesse em curto espaço de tempo. A velocidade de chegada da tecnologia de novas variedades lançadas no mercado é de sua importância para o setor (LIMA, 2010). 
O sucesso do cultivo in vitro e da introdução de um determinado genótipo nos programas de melhoramento utilizando a seleção in vitro, depende das condições de cultivo do meio de cultura (VILLA et al., 2014), do estado fisiológico da planta mãe de onde é retirado o explante (DELPORT et al., 2001) e, sobretudo, da capacidade do genótipo doador do explante de induzir calos embriogênicos e de sua posterior regeneração em plantas (GANDONOU et al., 2005). A fonte de carbono adicionada ao meio de cultura influí significativamente o desempenho do cultivo, devido aos seus efeitos sobre o aporte de energia para o explante e a manutenção do potencial osmótico do meio (RIBEIRO et al., 2015).

O genótipo do material influência de forma acentuada a morfogenia necessitando adaptações nos protocolos das cultivares em multiplicação (CIDADE et al., 2006). Os reguladores de crescimento fornecidos no meio de cultura repõem as ausências dos hormônios dos explantes que estão isolados no meio e desprendidos da planta matriz (SCHMILDT et al., 2007).

A retirada dos explantes para a formação de calos embriogênicos ocorrem nas folhas jovens, próximos ao meristema (TAYLOR; DUKIC, 1993; LAKSHMANAN et al., 2006; GARCIA et al., 2007; JOYCE et al., 2010), com idade de 6 a 15 meses (GILL et al., 2006). A utilização de sementes (CHENGALRAYAN; GALLO-MEAGHER, 2005) e palmitos com formação de inflorescência são fontes eficientes de explantes para a obtenção de calos embriogênicos (SNYMAN et al., 2006), e eficiência na regeneração de plântulas (GILL et al., 2006). Franklin et al. (2006), conseguiram calos embriogênicos e plântulas utilizando segmentos da bainha de folhas de cana-de-açúcar.

A propagação e a manipulação in vitro da cana-de-açúcar apresentam grandioso avanço tecnológico nas regiões do planeta em que a cultura está mais desenvolvida, onde biofábricas (LEE et al., 2007) e sistemas automatizados (KAIZU et al., 2002) viabilizaram-se para a geração em larga escala de material propagativo sadio com origem genética assegurada.

A comercialização de plantas micropropagadas de cana-de-açúcar foi introduzida no Brasil a partir da década de 80 , com o objetivo de produzir mudas com características genéticas originais e excelente grau de fitossanidade. Entretanto, os mecanismos de eliminação dos microrganismos patogênicos através da micropropagação podem promover a eliminação das bactérias diazotróficas endofíticas que são benéficas (CANUTO et al., 2003).

\section{CULTURA DE MERISTEMAS}

Cultura de meristemas são técnicas aplicadas para a regeneração de plantas sadias através do uso de meristemas apicais (VENDRUSCOLO, 2012). Termignoni (2005), diz que "meristemas são as estruturas apicais, incluindo o domo apical e os dois primórdios foliares que se situam neste extremo ápice da planta", ao passo que "ápices são os dois últimos centímetros do eixo caulinar e segmentos caulinares, incluindo o ápice caulinar com as gemas axilares que se situam junto às folhas". A cultura de tecidos vem sendo adotado por alguns motivos entre eles redução no tempo de multiplicação de clones e de variedades garantindo a produção de material propagativo em menor espaço de tempo (HENDRE et al., 1983).

A ausência de feixes vasculares neste tecido meristemático devido à idade deste (TERMIGNONI, 2005); a organização estrutural do tecido que permite o desenvolvimento da parte aérea sem a necessidade de passar pela fase de calo (TORRES et al., 1998); a facilidade de obtenção pelo número inicial de explantes obtidos da planta-mãe, pela viabilidade in vitro e pelo rápido crescimento são características importantes que garantem a eficiência da técnica (VENDRUSCOLO, 2012). Para Donato et al. (2005) e Torres et al. (1998), a utilização do processo de limpeza clonal a partir da cultura de meristemas não garante totalmente a sanidade do tecido meristemático da cana-de-açúcar.

De acordo com Torres et al. (1998) e Parmessur et al. (2002), a pequena dimensão e o desbalanço hormonal na região de cultivo, acarretam, normalmente, grande dificuldade de obtenção do explante e na regeneração das plantas. A sanidade da planta é, também, um fator 
determinante na capacidade de organogênese (TORRES et al., 1998), bem como a ocorrência do patógeno e sua ação diferenciada nos diferentes órgãos da planta (GIORIA et al., 2002).

Uma notável vantagem desse sistema é, na maioria dos casos, a manutenção do genótipo regenerado, em virtude de as células meristemáticas manterem de modo uniforme a sua estabilidade genética.

Alguns autores como Hendre et al. (1983) e Alegria et al. (2003) relataram a eliminação de vírus como o SCMV e o SrMV das plantas de cana-de-açúcar infectadas partindo-se de ápices meristemáticos medindo de 0,3 a $1 \mathrm{~mm}$ em meio de cultura, sem a adição de ribavirina.

\section{CALOS DE CANA-DE-AÇÚCAR}

Segundo Fumis e Brasil (1995), a regeneração de cana-de-açúcar a partir de calos já foram estudas por Barba e Nickell (1969). Para Santos et al. (2008), a micropropagação em plantas pela regeneração de calos também chamada de organogênese indireta pode ser considerada um método potencial de propagação, caso as variações genéticas também chamada de variação somaclonal não atinjam altos valores.

Processos de organogênese somática ou formação de calos tem como objetivo sob determinadas circunstâncias, de se multiplicar o material selecionado com maior velocidade o que contribui grandiosamente para programas de melhoramento genético da cana (CIDADE et al., 2006).

Segundo Rosado et al. (2009), para que ocorra melhores condições do cultivo in vitro é necessária adição de reguladores de crescimento ao meio de cultivo. $O$ intuito é de atender as possíveis necessidades endógenas do ambiente como condições de cultivo do meio de cultura, das condições fisiológicas da planta doadora (GOMES et al., 2009). Há uma grande variação com o uso de diferentes genótipos, explantes e interação do ácido naftalenoacético (ANA) e benzilaminopurira (BAP) com outros fitorreguladores (ROSADO et al., 2009). Gandonou et al. (2005) diz que o genótipo doador do explante da cana possui a capacidade de induzir calos embriogênicos e de sua posterior regeneração. O mesmo autor diz ainda que é necessário conhecer o grau de resistência da espécie estudada face ao fator de estresse, determinando-se as doses do agente estressor a serem adicionados ao meio de cultura. Gomes et al. (2009) estudando resposta de calos embriogênicos de cana-de-açúcar (Saccharum officinarum L.) a diferentes concentrações de cloreto de sódio observaram que calos da variedade SP 813250 são mais resistentes ao $\mathrm{NaCl}$ em comparação aos calos da RB 72454. Ainda verificaram que a presença de $\mathrm{NaCl}$ no meio de cultura afeta a embriogênese somática indireta em cana-de-açúcar.

\section{EMBRIOGÊNSE SOMÁTICA}

Em cana-de-açúcar, a rota morfogenética mais estudada e utilizada para regeneração de plantas é a embriogênese somática. O processo foi estudado pela primeira vez há aproximadamente 50 anos por Steward et al. (1958) e Reinert (1959) e continua sendo objeto de estudo, devido a sua grande importância. É dividida em indução e expressão, onde a indução ocorre por meio de reguladores de crescimento vegetal acrescidos ao meio de cultura, bem como as auxinas sintéticas; e a expressão é a fase em que as células mostram sua competência em se diferenciar em embriões somáticos (JIMÉNEZ, 2005).

A cana-de-açúcar foi uma das primeiras espécies vegetais a ser regenerada in vitro com sucesso (BARBA e NIKELL, 1969). Desde então, muitos estudos têm sido realizados em cana-deaçúcar, principalmente para obtenção da embriogênese somática (GANDONOU et al., 2005; LAKSHMANAN et al., 2006; JOYCE et al., 2010; MUDRY et al., 2013).

No entanto, as pesquisas apontam que há muita variação somaclonal neste processo, causando anormalidades morfológicas (BURNER e GHISHAM, 1995; JOYCE et al., 2010). A indução de calos em cana-de-açúcar ocorre tradicionalmente em meio de cultura MS (MURASHIGE e 
SKOOG, 1962). Sendo que, diferenças na indução de calos embriogênicos são observadas com relação ao regulador de crescimento utilizado. As auxinas sintéticas mais comumente utilizadas são: ácido 4-amino-3,5,6-tricloro-2-piridinecarboxílico (Picloram) (GARCIA et al., 2007), ácido 3,6dicloro-2-metoxibenxzóico (Dicamba) (KHAN et al., 2008) e o ácido 2,4-Diclorofenoxiacético (2,4D) (GANDONOU et al., 2005; WATT et al., 2009), que é o mais utilizado para cultura de cana-deaçúcar.

Como mencionado, em cana-de-açúcar, os explantes para a formação de calos embriogênicos são retirados de folhas jovens, próximos ao meristema, no entanto, alguns pesquisadores afirmam que a utilização de sementes (CHENGALRAYAN; GALLO-MEAGHER, 2005) e palmitos com formação de inflorescência, são fontes de eficientes de explantes para a obtenção de calos embriogênicos (SNYMAN et al., 2006), e maior regeneração de plântulas (GILL et al., 2006). Franklin et al. (2006), utilizando segmentos da bainha de folhas de cana-de-açúcar, conseguiram calos embriogênicos e plântulas.

A cana-de-açúcar é um híbrido interespecífico, deste modo que, cada cultivar possui um comportamento, tanto in vitro quanto no campo, onde a resposta morfogenética é bastante influenciada pelo genótipo em questão. Lima et al. (2001) relatam que alguns cultivares apresentam elevada formação de calos mucilaginosos sem formação de plântulas, enquanto outros possuem grande capacidade de formação de calos embriogênicos e regeneração de plantas. Gandonou et al. (2005) comparando a resposta de nove genótipos em meio MS com $3 \mathrm{mg}$ $\mathrm{L}^{-1}$ de $2,4-\mathrm{D}$, observou diferenças significativas entre esses como, por exemplo, a capacidade de indução e regeneração de plantas, indicando que esses critérios são dependentes do genótipo. Já Alcantara et al. (2014) estudando regeneração de plantas a partir de embriões somáticos, nas cultivares de cana-de-açúcar RB855156 e RB72454, obtiveram taxa de sobrevivência de 100\% para ambas as cultivares e as análises histológicas revelaram que a origem das brotações em ambas as cultivares ocorreu via embriogênese somática Os genótipos estudados são os mais variados, e as pesquisas são realizadas com os cultivares adaptados a cada região de cultivo e exploração econômica.

Outro fator de influência na obtenção de calos embriogênicos é a intensidade luminosa, para a cultura da cana-de-açúcar, a embriogênese somática ocorre no escuro (GANDONOU et al., 2005; LAKSHAMANAN, 2006; JOYCE et al., 2010), pois há maiores taxas de formação de calos nesse ambiente, em comparação com locais sob intensidade luminosa (GARCIA et al., 2007). A temperatura também possui influencia sob a formação de calos embriogênicos de cana-de-açúcar. Segundo Ali et al. (2008) a indução e proliferação desses calos ocorreram em temperatura aproximada de $27^{\circ} \mathrm{C} \pm 1{ }^{\circ} \mathrm{C}$.

Esses dois fatores, temperatura e luminosidade, são pouco estudados, apesar de influenciarem na embriogênese somática de cana-de-açúcar (GARCIA et al., 2007). Vários estudos relatam que o 2,4-D aumenta os níveis de auxina endógena nos explantes responsivos e por esse motivo é mais eficiente na resposta indutiva dos tecidos. Porém, a manutenção prolongada dos embriões neste regulador e repetidos subcultivos, podem causar instabilidade genética (GILL et al., 2006) e aumentar a probabilidade de variação somaclonal (BURNER e GRISHAM, 1995; FRANKLIN et al., 2006; LAKSHMANAN et al., 2006), afetando o potencial embriogênico em cana-de-açúcar.

\section{CONSERVAÇÃO DE GERMOPLASMA IN VITRO (INTRODUÇÃO)}

Um grande número de espécies de plantas cultiváveis possui sementes, as quais são classificadas como ortodoxas e podem ser desidratadas até baixos teores de umidade e assim podem ser estocadas a baixas temperaturas por um período de tempo estendido (ROBERTS, 1973). Há três principais categorias de espécies de plantas nas quais a conservação na forma de semente é problemática. Primeiramente, plantas tais como banana e plátano que não produzem sementes e são, portanto propagadas vegetativamente. Segundo, algumas espécies tais como 
batata ou cana de açúcar, nas quais possuem tanto genótipos estéreis como genótipos que produzem sementes ortodoxas. No entanto, estas sementes são geralmente altamente heterozigotas e são portanto, de baixo interesse de serem conservadas. Estas espécies são, portanto, principalmente mantidas como clones. Terceiro, uma numerosa variedade de espécies frutíferas e florestais que produzem sementes recalcitrantes, sementes que não podem ser secas a níveis de umidade suficientemente baixos que permitiria uma estocagem a baixas temperaturas (ROBERTS, 1973). Há também um grande número de espécies, classificadas como intermediária (ELLIS et al., 1990,) nas quais a conservação na forma de sementes ainda é problemática. O método convencional de conservação ex situ para estas categorias de plantas é em forma de coleções de campo. Conservação a campo apresenta grandes gargalos, os quais limitam sua eficácia e ameaça a seguridade dos recursos genéticos de plantas conservadas desta forma.

O desenvolvimento da biotecnologia leva a produção de uma nova categoria de germoplasma incluindo clones obtidos de germoplasma elite, linhagens celulares com atributos especiais e materiais geneticamente transformados (ENGELMANN, 1992). Este tipo de germoplasma é sempre de grande valor agregado e muito difícil de ser produzido. $O$ desenvolvimento de técnicas eficientes para garantir uma conservação segura, é portanto, de extrema importância.

Diante dos problemas apresentados nas diferentes categorias das espécies de plantas representadas a cima, não é uma surpresa que muitos esforços têm sido feitos com intuito de aprimorar a qualidade e seguridade da conservação oferecida nos bancos de germoplasma a campo e jardins botânicos. No entanto, está claro que métodos alternativos para a conservação genética são necessários para estes materiais especiais, e desde o início dos anos 70, as atenções têm sido voltadas pelas possibilidades oferecidas pela biotecnologia, especialmente cultura de tecidos in vitro.

Técnicas de cultura de tecidos são de grande interesse para coleta, multiplicação e armazenamento de germoplasma. (ENGELMANN, 1991; BUNN et al., 2007). O sistema de cultura de tecidos permite a propagação com altas taxas de multiplicabilidade em um ambiente asséptico. Plantas livres de vírus podem ser obtidas através da cultura de meristemas em combinação com termoterapia, assim assegurando a produção de lotes livres de doenças e simplificando os procedimentos de quarentena para um intercâmbio internacional de germoplasma. A miniaturização de explantes permite reduzir o requerimento de espaços e consequentemente os custos com mão-de-obra na manutenção de coleções de germoplasma. Os protocolos de propagação in vitro tem sido estabelecidos por vários milhares de espécies de plantas (GEORGE, 1996), incluindo várias espécies raras ou em extinção (FAY, 1992; SARASAN et al., 2006). Vários métodos de conservação in vitro são empregados, dependendo da demanda do período de armazenamento. Para armazenamento a médio e curto prazo, o objetivo é reduzir o crescimento e aumentar o intervalo entre subculturas. Para armazenamento a longo prazo, a criopreservação (armazenamento a temperaturas ultra-baixas, normalmente usando nitrogênio líquido $\left(-196{ }^{\circ} \mathrm{C}\right)$ é o único método empregado. Nessa temperatura, toda divisão celular e processos metabólicos são cessados. $O$ explante pode, então, ser armazenado sem alteração ou modificação, teoricamente, por um período de tempo ilimitado. Além disso, culturas que são armazenadas em um pequeno volume, protegidas de contaminação, requerem quase nenhuma manutenção.

A preservação in vitro usando criopreservação (ENGELMANN, 1991, 2004; GONZÁLESARNAO; ENGELMANN, 2006) e preservação sob crescimento mínimo (PAULET et al., 1993; TAYLOR; DUKIC, 1993; LEMOS et al., 2002; WATT et al., 2009; CHANDRAN, 2010) tem sido explorado por vários autores na cultura da cana-de-açúcar aliviando o dia-a-dia dos cientistas e aumentando a capacidade nas câmaras de crescimento e casas de vegetação. Além disso, estes estudos facilitaram a manutenção e preservação de linhas selecionadas sem a necessidade de 
transferências para o campo e, em caso de materiais transgênicos, sem as permissões regulatórias associadas a este trabalho.

\section{CONSERVAÇÃO DE GERMOPLASMA IN VITRO EM CANA-DE-AÇUCAR CONSERVAÇÃO IN VITRO COM CRESCIMENTO MÍNIMO (CONSERVAÇÃO A MÉDIO CURTO PRAZO)}

Crescimento mínimo se refere ao restringimento do crescimento e da morfogênese in vitro através do decréscimo da temperatura, nutrientes, disponibilidade de sucrose, alterações no fotoperíodo (GARCIA et al., 2007), presença ou ausência de reguladores de crescimento e adição de substâncias osmóticas (ENGELMANN, 1991; SHIBLI et al., 2006), tecido de origem do explante inicial (FRANKLIN et al., 2006; ALI et al., 2008), entre outros. Recentemente, foram desenvolvidos protocolos para o armazenamento in vitro de embriões e plântulas de cana de açúcar. Embriões somáticos imaturos podem ser mantidos no escuro com $50 \%$ de MS com $5 \mathrm{~g} \mathrm{~L}^{-1}$ de sucrose por 12 semanas a $18{ }^{\circ} \mathrm{C}$ ou $24{ }^{\circ} \mathrm{C}$ (WATT et al., 2009. O armazenamento de plântulas totalmente regeneradas é, no entanto, uma opção mais viável, já que estes podem ser mantidos in vitro de 812 meses (PAULET et al., 1993; TAYLOR; DUKIC, 1993; LEMOS et al., 2002; WATT et al., 2009; CHANDRAN, 2010). A base para o sucesso no armazenamento de plântulas é a combinação de redução de temperatura $\left(18^{\circ} \mathrm{C}\right), 50 \%$ de concentração de $\mathrm{MS}$ basal contendo baixa concentração de sucrose (10-20 $\mathrm{g} \mathrm{L}^{-1}$ ) em meio semissólidos e na ausência de reguladores de crescimento (TAYLOR; DUKIC, 1993; WATT et al., 2009). O manitol tem sido usado para manter plantas em meio liquido por quatro meses a $25{ }^{\circ} \mathrm{C}$ (CHANDRAN, 2010). Enquanto a adição de um $\mathrm{mg} \mathrm{L}^{-1}$ de ácido abicísico ( $A B A$, um retardador de crescimento) em meio líquido facilitou o armazenamento de plântulas por 52 semanas a $15{ }^{\circ} \mathrm{C}$ (LEMOS et al., 2002). Análises morfológicas ou por meio de analises AFLP não mostraram diferença significativa entre plantas não armazenadas e armazenadas depois da aclimatização (TAYLOR; DUKIC, 1993; WATT et al., 2009). Consequentemente, em muitas organizações, o germoplasma de cana de açúcar tem sido armazenado sob condições de crescimento mínimo, como por exemplo, o centro de cooperação internacional e pesquisa agronômica na França, centro de pesquisa federal da Austrália, instituto de melhoramento de cana-de-açúcar da Índia e o centro de pesquisa em tecnologia canavieira (CTC), Piracicaba-Brasil. No entanto, como discutiremos abaixo, protocolos para preservação de germoplasmas usando outros métodos mais eficientes são bem vindos, como é o caso da criopreservação, lembrando que, neste caso, há uma maior necessidade de protocolos germoplasma específico.

\section{CRIOPRESERVAÇÃO \\ CONSERVAÇÃO A LONGO PRAZO}

Criopreservação é a única técnica atualmente disponível que assegura a seguridade e a eficiência em custo da conservação de germoplasma a longo prazo.

\section{TÉCNICAS DE CRIOPRESERVAÇÃO}

Alguns materiais, tais como sementes ortodoxas ou gemas dormentes apresentam processo de desidratação natural e podem ser criopreservadas sem nenhum pré-tratamento. No entanto, a maioria dos sistemas experimentais empregados em criopreservação (suspensões celulares, calos, gemas apicais, embriões) contem altas quantidades de água celular e são assim extremamente sensíveis a injúria por congelamento desde que a maioria delas não sejam hereditariamente tolerantes ao congelamento. As células assim têm que ser desidratadas artificialmente para protegê-las dos danos causados pela cristalização da água intracelular até o estágio de gelo (MAZUR, 1984). As técnicas empregadas e os mecanismos físicos sobre os quais elas estão inseridas, estão baseadas em técnicas de criopreservação modernas e clássicas. 
(WITHERS; ENGELMANN, 1998). Técnicas clássicas envolve desidratação induzida pelo congelamento, enquanto técnicas modernas estão baseadas em vitrificação. Vitrificação pode ser definida como uma transição de água diretamente da fase líquida para a fase amorfa ou vítreo, evitando a formação da fase cristalina (FAHY et al., 1984).

\section{TÉCNICAS DE CRIOPRESERVAÇÃO CLÁSSICAS}

Estas técnicas envolvem resfriamento lento até uma temperatura de pré-congelamento definida, seguida por uma rápida imersão em nitrogênio líquido. Com a redução de temperatura durante o resfriamento lento, as células e o meio externo inicialmente superresfriam, seguido pela formação de gelo no meio (MAZUR, 1984). A membrana celular age como uma barreira física e previne a formação de gelo do interior das células do material propagativo, e as células permanecem não congeladas, mas super-resfriadas. Como a temperatura é muito diminuída, uma quantidade crescente de solução extracelular é convertida em gelo, assim resultando na concentração de solutos intracelulares. Desde que as células permaneçam super. resfriadas e sua pressão de vapor aquoso exceda aquela do comportamento externo congelado, as células se equilibram pela perda de água para o gelo externo. Dependendo da taxa de congelamento e da temperatura de pré-congelamento, quantidades diferentes de água sairão das células antes que o conteúdo intracelular solidifique. Em condições ótimas, a maioria ou toda água intracelular congelável é removida, assim reduzindo ou evitando a formação de gelo intracelular detrimental sobre uma imersão subsequente no nitrogênio líquido. No entanto, a desidratação induzida por congelamento de forma muito drástica pode causar eventos danosos devido à concentração de sais intracelular e mudanças na membrana celular (MERYMAN et al., 1977). Todo cuidado deve ser tomado para evitar o fenômeno da recristalização no qual o gelo derrete e é reformado em um tamanho cristalizado, maior, termodinamicamente mais favorável a provocar danos (MAZUR, 1984). Procedimentos de congelamento clássicos incluem os passos seguintes: pré-crescimento de amostras, criopreservação, baixo resfriamento $\left(0,5-2,0{ }^{\circ} \mathrm{C} \mathrm{min}{ }^{-1}\right)$ a uma determinada temperatura de pré-congelamento (normalmente ao redor de $-40{ }^{\circ} \mathrm{C}$ ), imersão rápida de amostras em nitrogênio líquido, armazenamento, rápida liquefação e recuperação. Técnicas clássicas são geralmente operacionalmente complexas já que elas requerem o uso de freezers programáveis sofisticados e caros. Em muitos casos, o uso destes pode ser evitado através do ato de resfriamento lento com um freezer doméstico ou laboratorial (KARTHA; ENGELMANN, 1994). Técnicas de criopreservação têm sido aplicadas com sucesso em sistemas de cultura indiferenciados tais como suspensões celulares, caloses (KARTHA; ENGELMANN, 1994; WITHERS; ENGELMANN, 1998).

\section{TÉCNICAS DE CRIOPRESERVAÇÃO MODERNAS.}

Nos procedimentos baseados em vitrificação, a desidratação celular é realizada antes do congelamento pela exposição de amostras a meios crioprotectivos concentrados e/ou dessecação por ar. Isto é seguido por um resfriamento rápido. Na ordem de $100{ }^{0} \mathrm{C} \mathrm{min}^{-1}$. Como resultado, todos os fatores que afetam a formação de gelo intracelular são evitados. Transições vítreas (Mudanças na conformação estrutural de vítreo) durante o congelamento têm sido utilizadas com vários materiais usando analises térmicas (DEREUDDRE et al., 1991; NIINO et al., 1992). Procedimentos baseados em vitrificação oferecem vantagens práticas em comparação com técnicas de congelamento. Com congelamento ultrarrápido, estes são mais apropriados para órgãos mais complexos (gemas apicais, embriões), os quais contêm uma variedade de tipos de células, cada um com requerimentos singulares sob condições de desidratação induzidas pelo congelamento. Pela prevenção da formação de gelo no sistema, procedimentos baseados em vitrificação são operacionalmente menos complexos do que os clássicos (estes não requerem o uso de freezers controlados) e tem um grande potencial de aplicabilidade ampla, requerendo 
somente modificações menores por diferentes tipos de células (ENGELMANN, 1997). Um recurso comum para todos estes novos protocolos é que o passo crítico para alcançar a sobrevivência é o passo da desidratação e não o passo de congelamento, como nos protocolos clássicos. Portanto, se amostras para serem congeladas são passíveis a dessecação até conteúdos de água suficientemente baixos (os quais variam dependendo no procedimento empregado e o tipo e características dos propágulos a serem congelados) com nenhuma ou muito pouca diminuição em sobrevivência em comparação com controles não desidratados, com nenhuma queda ou queda muito limitada na sobrevivência é geralmente observada depois da criopreservação.

\section{CRIOPRESERVAÇÃO EM CANA-DE-ACÚCAR}

A base biológica para o sucesso da criopreservação alenta sobre a retirada da água celular (desidratação celular) antes do resfriamento, com o intuito de minimizar a ocorrência de cristais, ao mesmo tempo mantendo a viabilidade celular. Neste princípio, muitos métodos têm sido empregados para a preparação de explantes para armazenamento a $-196{ }^{\circ} \mathrm{C}$ (ENGELMANN, 2000; GONZÁLES-BENITO; PEREZ, 2004; SHIBLI et al., 2006; GONZÁLES-ARNAO et al., 2008), incluindo desidratação física (por exemplo, secagem a ar em fluxo laminar ou sobre sílica gel) e o suprimento exógeno de substâncias crioprotetoras, exemplo, sucrose, dimethylsuphoside (DMSO) e glicerol (MULDREW et al., 2004). Recentemente, o método favorito para a maioria das culturas, incluindo cana de açúcar é a vitrificação que é a remoção rápida da maioria ou de toda água congelável antes do resfriamento rápido, o qual resulta em vitrificação dos solutos internos (GONZÁLES-ARNAO et al., 2008). Como um meio de prover proteção durante o manuseio, os explantes são encapsulados em alginato de sódio antes da secagem, um método conhecido como encapsulamento/desidratação (ENGELMANN, 2004; GONZÁLES-BENITO; PEREZ, 2004; GONZÁLESARNAO et al., 2008).

Os primeiros trabalhos com criopreservação de explantes de cana de açúcar focaram em suspensões celulares com o trabalho de Finkle e Ulrich (1979), relatando que o meio mais eficiente de preservação dos explantes era a combinação binária de crioprotetores tais como glucose, DMSO e etileno glicol. Outro método relatado de sucesso ( $92 \%$ de eficiência) para células embriogênicas de cana de açúcar envolve o pré-tratamento com sorbitol, criopreservação com DMSO e sorbitol e resfriamento lento $-40{ }^{\circ} \mathrm{C}$ antes da rápida imersão em nitrogênio líquido seguido por uma liquefação rápida (GNANAPRAGASAM; VASIL, 1990). DMSO e sucrose tem sido também incluído em combinações de crioprotetores (EKSOMTRAMAGE et al., 1992; CHANPRAME et al., 1993) e provados como benéficos na preservação tanto de gemas meristemáticas como explantes de calos (BAJAJ; JIAN, 1995; GONZÁLES-ARNAO et al., 2008). O processo de criopreservação pelo método encapsulamento/desidratação envolve encapsulamento dos explantes em alginato, seguido pela pré-cultura sobre um meio suplementado com altas concentrações de sucrose, desidratação em fluxo laminar ou sobre sílica gel, congelamento a -196 ${ }^{\circ} \mathrm{C}$ e reaquecimento lento. Este método possui inúmeras vantagens, tais como fácil manuseio de amostras, meio crioprotetor simplificado, custo reduzido com equipamentos e sobrevivência de explantes maiores (GONZÁLES-ARNAO; ENGELMANN, 2006; GONZÁLES-ARNAO et al., 2008). A taxa de sobrevivência de meristemas de cana-de-açúcar de cinco variedades criopreservadas usando encapsulamento/desidratação variou de 38 a 91\%, baseado sobre o número de ápices que produziram gemas depois da liquefação (PAULET et al., 1993). Taxas de sobrevivência similar (3890\% e $21-81 \%)$ foram relatadas quando gemas produzidas de meristemas criopreservados de três ou seis variedades diferentes foram avaliadas (GONZALES-ARNAO; ENGELMANN, 2006). O sucesso de protocolos de crioarmazenamento para cana de açúcar é influenciado pelo genótipo, desconsiderando o tipo de explantes utilizado. Por exemplo, recrescimento de calos depois da retirada do nitrogênio líquido obteve taxas de viabilidade variando de 3 a 92\% para 15 cultivares diferentes de cana-de-açúcar (EKSOMTRAMAGE et al., 1992). Similarmente, o efeito de um 
genótipo foi mostrado com o uso de meristemas criopreservados: 20-40\% (PAULET et al., 1993) e 24-91\% (GONZALES-ARNAO; ENGELMANN, 2006) de sobrevivência foi observado sobre vários genótipos de cana de açúcar testados. Não há diferenças em características morfológicas ou isoenzimáticas em plantas recuperadas de ápices criopreservados de três cultivares de cana de açúcar estocados por 12 horas, 10 dias, 4, 6 ou 12 meses (GONZALES-ARNAO; ENGELMANN, 2006). Para assegurar a veracidade da conservação do germoplasma parental, isto é fundamental que as plantas regeneradas dos explantes criopreservados retém a fidelidade genética e fenotípica de tal forma que técnicas de armazenamento e subsequentes manipulações não induzam variações somaclonais. A esse respeito, Paulet et al. (1993) não descobriu nenhum fenótipo diferente entre plantas derivadas de ápices criopreservados e ápices controle em padrões eletroforéticos isoenzimáticos. Similarmente, nenhuma variação foi detectada entre cana-de-açúcar plantada a campo propagada de meristemas criopreservados e controles não tratados, considerando características botânicas (forma e tamanho da aurícula foliar, lígula e colar) e características agronômicas (peso de caule, diâmetro e altura e brix (ORTIZ et al., 2000).

\section{CONSIDERAÇÕES FINAIS}

Há um amplo espectro de uso para os numerosos e bem estabelecidos protocolos para a manipulação in vitro de morfogênese em cana-de-açúcar. O prospecto de produzir novas características via indução da variação somaclonal e experimentação in vitro para tolerância a pragas e doenças não foi ainda amplamente explorado. Enquanto benefícios do crescimento mínimo são reconhecidos na conservação de germoplasmas in vitro de cultivares elite de cana de açúcar, e todo potencial positivo desta técnica e da criopreservação pode ainda ser expandida. Por outro lado, técnicas na produção em massa de genótipos fidedignos superiores, livres de patógenos, já tem sido integrado em muitos programas de melhoramento de cana-de-açúcar.

\section{REFERÊNCIAS}

AGRIANUAL: Anuário da agricultura brasileira. 21. ed. São Paulo: FNP Consultoria \& Agroinformativos, 2016. 484 p.

ANDRADE, S.R.M. de. Principios da cultura de tecidos vegetais. Planaltina - DF, Embrapa cerrados, Documentos n. 58, 2002, 16p

ALCANTARA, G.B.; DIBAX, R.; OLIVEIRA, R.A.; FILHO, J.C.B.; DAROS, E. Plant regeneration and histological study of the somatic embryogenesis of sugarcane (Saccharum spp.) cultivars RB855156 and RB72454. Acta Scientiarum Agronomy, v.36, n.1, p.63-72, 2014. https://doi.org/10.4025/actasciagron.v36i1.16342

ALEGRIA, O.M., ROYER, M., BOUSALEM, M., CHATENET, M., PETERSCHMITT, M., GIRARD, J.C.; ROTT, P. Genetic diversity in the coat protein coding region of eighty-six Sugarcane mosaic virus isolates from eight countries, particularly from Cameroom and Congo. Archives of Virology, v.148, p.357-372, 2003. https://doi.org/10.1007/s00705-002-0916-1

ALI, A.; NAZ. S.; SIDDIQUI, F.A.; IQBAL, J. Rapid clonal multiplication os sugarcane (Saccharum officinarum) though callogenesis and organogenesis. Pakistan Journal of Botanic, v.40, n.1, p.23138, 2008.

ARENCIBIA, A.D.; BERNAL, A.; YANG, L.; CORTEGAZA, L.; CARMONA, E.R.; PEREZ, A.; HU, C.J.; LI, Y.R.; ZAYAS, C.M.; SANTANA, I. New role of phenylpropanoid compounds during sugarcane micropropagation in Temporary Immersion Bioreactors (TIBS). Plant Science, v.175, n.4, 2008, 
p.487-496, 2008. https://doi.org/10.1016/j.plantsci.2008.05.024

BAJAJ, Y.P.S.; JIAN L.C. Cryopreservation of sugarcane (Saccharum spp.). In: BAJAJ Y.P.S. Biotechnology in agriculture and forestry, Cryopreservation of plant germplasm I. Springer, v.32. p.256-265, 1995. https://doi.org/10.1007/978-3-662-03096-7 17

BARBA, R.; NICKELL, L.G. Nutrition and organ differentiation in tissue culture of sugarcane - a monocotyledon. Planta, v.89, p.299-302, 1969. https://doi.org/10.1007/BF00385034

BASTOS, L.P.; MOREIRA. M.J.S.; COSTA, M.A.P. de C; ROCHA, M.C. da; HANSEN, D. de S.; SILVA, S.A.; DANTAS, A.C V.L.; SOUSA, C. da S. Cultivo in vitro de mangabeira (Hancornia speciosa). Revista Brasileira de Biociências, v.5, supl.2, p.1122-1124, 2007.

BUNN, E.; TURNER S.R.; PANAIA M.; DIXON, K.W. The contribution of in vitro technology and cryogenic storage to conservation of indigenous plants. Australian Journal of Botany, v.55, n.3, p.345-355, 2007. https://doi.org/10.1071/BT06065

BURNER, M.D.; GRISHAM, M.P. Induction and stability of phenotypic variation in sugarcane as affected by propagation procedure. Crop Science Society of America, v.35, p.875-880, 1995. https://doi.org/10.2135/cropsci1995.0011183X003500030040x

CANUTO, E. de L.; SALLES, J.F.; OLIVEIRA, A.L.M.; PERIN, L.; REIS, V.M.; BALDANI, J.I. Respostas de plantas micropropagadas de cana-de-açúcar à inoculação de bactérias diazotróficas endofíticas. Agronomia, v.37, n.2, p. 67-72, 2003.

CHANDRAN, K. In vitro multiplication and conservation of saccharum germplasm. Indian Journal of Plant Genet Resour, v.23, n.1, p.65-68, 2010.

CHANPRAME, S.; LERSRUTAIYOTIN, R.; WEERASATHAKUL, C. Effect of cryoprotectants on cryopreservation of sugarcane cells. National Science, v.27, p.1-3, 1993.

CHENGALRAYAN, A. A.; GALLO-MEAGHER, A. In vitro regeneration of plants from sugarcane seedderived callus. In Vitro Cellular \& Developmental Biology - Plant, v.41, n.4, p.477-482, 2005. https://doi.org/10.1079/IVP2005655

CIDADE, D.A. de P.; GARCIA, R. de O.; DUARTE, A.C.; SACHETTO-MARTINS, G.; MANSUR, E. Morfogênese in vitro de variedades brasileiras de cana-de-açúcar. Pesquisa Agropecuária Brasileira, v.41, n.3, p.385-391, 2006. https://doi.org/10.1590/S0100-204X2006000300003

DELPORT, F.; MOSTADE, O.; JACQUEMIN, J.M. Plant regeneration though callus initiation from thin mature embryo fragments of wheat. Plant Cell, Tissue and Organ Culture, v.67, p.73-80, 2001. https://doi.org/10.1023/A:1011697316212

DEREUDDRE, J.; HASSEN, M.; BLANDIN, S.; KAMINSKI, M. Resistance of alginate-coated somatic embryos of carrot (Daucus carota L.) to desiccation and freezing in liquid nitrogen: 2. Thermal analysis. CryoLetters, v.12, p.135-148, 1991. 
DONATO, V.M.T.S.; ANDRADE, A.G. de; TAKAKI, G.M. de C.; MARIANO, R. de L.R.; MACIEL, G.A. Plantas de cana-de-açúcar cultivadas in vitro com antibióticos. Ciência e Agrotecnologia, v.29, n.1, p.134-141, 2005. https://doi.org/10.1590/S1413-70542005000100017

EKSOMTRAMAGE, T.; PAULET, F.; GUIDERDONI, E.; GLASZMANN, J.C.; ENGELMANN, F. Development of a cryopreservation process for embryogenic calluses of commercial hybrid of sugarcane (Saccharum sp.) and application to different varieties. CryoLetters, v.13, p.239-252, 1992.

ELLIS, R.E.; HONG, T.; ROBERTS, E.H. An intermediate category of seed storage behaviour? I. Coffee. Journal of Experimental Botany, Oxford, v.41, p.1167-1174, 1990. https://doi.org/10.1093/jxb/41.9.1167

ENGELMANN, F. Cryopreservation of embryos. In: DATTÉE, Y.; DUMAS, C.; GALLAIS, A. Reproductive biology and plant breeding. Springer, p.281-290,1992. https://doi.org/10.1007/978-3$\underline{642-76998-627}$

ENGELMANN, F. Importance of cryopreservation for the conservation of plant genetic resources. In: ENGELMANN, F.; TAKAGI, H. Cryopreservation of tropical plant germplasm-current research progress and applications. JIRCAS, p.8-20, 2000.

ENGELMANN, F. In vitro conservation methods. In: FORD-LLOYD, B.V.; NEWBURRY, J.H.; CALLOW, J.A. Biotechnology and plant genetic resources: conservation and use. CABI, p.119-162,1997.

ENGELMANN, F. In vitro conservation of tropical plant germplasm-a review. Euphytica v. 57, p. 227-243, 1991. https://doi.org/10.1007/BF00039669

ENGELMANN, F. Plant cryopreservation: progress and prospects. In Vitro Cellular \& Developmental Biology - Plant, v.40, n.5, p.427-433, 2004. https://doi.org/10.1079/IVP2004541

FAHY, G.M.; MACFARLANE, D.R.; ANGELL, C.A.; MERYMAN, H.T. Vitrification as an approach to cryopreservation. Cryobiology, v.21, n.4, p.407-426, 1984. https://doi.org/10.1016/0011$\underline{2240(84) 90079-8}$

FAY, M.F. Conservation of rare and endangered plants using in vitro methods. In Vitro Cellular Developmetal Biology - Plant. v.28, n.1, p.1-4, 1992. https://doi.org/10.1007/BF02632183

FINKLE, B.J.; ULRICH, J.M. Effect of cryoprotectants in combination on the survival of frozen sugarcane cells. Plant Physiology, v.63, n.4, p.598-604, 1979. https://doi.org/10.1104/pp.63.4.598

FRANKLIN, G.; ARVINTH, S.; SHEEBA, C.J.; KANCHANA, M.; SUBRAMONIAN, N. Auxin pretreatment promotes regeneration of sugarcane (Saccharum spp. Hybrids) midrib segment explants. Plant Growth Regulation, v.50, p.111-119, 2006. https://doi.org/10.1007/s10725-006-9108-4

FUMIS, T.F.; BRASIL, O.G. Efeito do boro sobre os teores de proteína e atividade da peroxidase em calos de cana-de-açúcar (Saccharum spp. var NA56-79) in vitro. Scientia Agrícola, v.52, n.1, p.161163, 1995. https://doi.org/10.1590/S0103-90161995000100027 
GANDONOU, C.H.B.; ERRABII, T.; ABRINI, J.; IDAOMAR, M.; CHIBI, F.; SKALI-SENHAJI, N. Effect of genotype on callus induction and plant regeneration from leaf explantas of sugarcane (Saccharum ssp.). African Journal Biotechnology, v.4, n.4, p. 350-354, 2005.

GARCIA, R.; CIDADE, D.; CASTELLAR, A.; LIPS, A.; MAGIOLI, C.; CALLADO, C.; MANSUR, E. In vitro morfogenesis patterns from shoot ápices of sugarcane aredetermined by light and type on growth regulator. Plant Cell Tissue and Organ Culture, v.90, n.2, p.181-190, 2007. https://doi.org/10.1007/s11240-007-9235-2

GEORGE, E. F. Plant propagation by tissue culture. Part 2 - in practice. 2nd ed. Exegetics, Edington, 1996.

GILL, R.; MALHTRA, P.K.; GOSAL, S.S. Direct plant regeneration from cultured young leaf segments of sugarcane. Plant Cell Tissue and Organ Culture, v.84, n.2, p.227-231, 2006. https://doi.org/10.1007/s11240-005-9015-9

GIORIA, R.; ESPINHA, L.M.; REZENDE, J.A.M.; GASPAR, J.O.; KITAJIMA, E.W. Limited movement of Cucumber mosaic vírus (CMV) in yellow passion flower in Brazil. Plant Pathology, v.51, p.127-133, 2002. https://doi.org/10.1046/j.1365-3059.2002.00678.x

GNANAPRAGASAM, S.; VASIL, I.K. Plant regeneration from cryopreserved embryogenic cell suspension of a commercial sugarcane hybrid (Saccharum sp.). Plant Cell Rep, v.9, n.8, p.419-423, 1990. https://doi.org/10.1007/BF00232263

GOMES, I.A.; DANTAS, C.V.S.; MARQUES, M.T.A.; MACEDO, C.E.C. Resposta de calos embriogênicos de cana-de-açúcar (Saccharum officinarum L.) a diferentes concentrações de cloreto de sódio. Plant Cell Culture \& Micropropagation, v.5, n.2, p.94-100, 2009.

GONZALEZ-ARNAO, M.T.; ENGELMANN, F. Cryopreservation of plant germplasm using the encapsulation-dehydration technique: review and case study on sugarcane. Cryoletters, v.27, n.3, p.155-168, 2006.

GONZALEZ-ARNAO, M.T.; PANTA, A.; ROCAW, M.; ESCOBAR, R.H.; ENGELMANN, F. Development and large scale application of cryopreservation techniques for shoot and somatic embryo cultures of tropical crops. Plant Cell, Tissue and Organ Culture, v.92, n.2, p.1-13, 2008. https://doi.org/10.1007/s11240-007-9303-7

GONZALEZ-BENITO, M.E.; PEREZ, C. Cryopreservation of nodal explants of an endangered plant species (Centaurium rigualii Esteve) using the encapsulation-dehydration method. Biodiversity \& Conservation, v.6, n.4, p.583-590, 1997. https://doi.org/10.1023/A:1018337429589

GROUT, B.W. Meristem tip culture for propagation and virus elimination. Methods in Molecular Biology, Totowa, v.111, p.115-125, 1999. https://doi.org/10.1385/1-59259-583-9:115

HENDRE, R.R.; IVER, R.S.; KOTWAL, M.; KHUSPE, S.S.; MASCARENHAS, A.F. Rapid multiplication of sugarcane by tissue culture. Sugar Cane, v.1, p.5-8, 1983.

JIMÉNEZ, V.M. Involvement of plant hormones and plant growth regulators on in vitro somatic embryogenesis. Plant Growth Regulation, v.47, n.2, p.91-110, 2005. https://doi.org/10.1007/s10725$\underline{005-3478-x}$ 
JOYCE, P.; KUWAHATA, M.; TURNER, N.; LAKSHMANAN, P. Selection system and cocultivation medium are important determinants of Agrobacterium-mediated transformation of sugarcane. Plant Cellular Reports, v.29, n.2, p.173-183, 2010. https://doi.org/10.1007/s00299-009-0810-3

KAIZU, Y.; OKAMOTO, T.; IMOU, K. Shape recognition and growth measurement of micropropagated sugarcane. Agricultural Engineering International E Journal, Manuscript IT 02003, v.4, p.1-16, 2002.

KARTHA, K.K.; ENGELMANN, F. Cryopreservation and germplasm storage. In: Vasil I. K.; Thorpe T. A. Plant cell and tissue culture. Kluwer, p.195-230, 1994.

KAUR, A.; SANDHU, J.S. High throughput in vitro micropropagation of sugarcane (Saccharum officinarum L.) from spindle leaf roll segments: Cost analysis for agri-business industry. Plant Cell, Tissue and Organ Culture, v.120, n.1, p.339-350, 2015. https://doi.org/10.1007/s11240-014-0610-5

KHAN, I.A.; DAHOT, M.U.; SEEMA, N.; BIBI, S.; KHATRI, A. Genetic variability in plantlets derived from callus culture in sugarcane. Pakistan Journal of Botany, v.40, n.2, p.547-564, 2008.

KNEIFEL, W.; LEONHARDT, W. Testing of different antibiotics against Gram-positive and Gramnegative bacteria isolated from plant tissue culture. Plant cell, tissue and organ culture, v.29, n.2, p.139-144, 1992. https://doi.org/10.1007/BF00033619

LAKSHMANAN, P. Invited review addendum: somatic embryogenesis in sugarcane - an addendum to the invited review 'sugarcane biotechnology: the challenges and opportunities'. In Vitro Cellular Developmental Biology - Plant, v.41, n.4, p.345-363, 2006. https://doi.org/10.1079/IVP2006772

LAKSHMANAN, P.; GEIJSKES, R.J.; WANG, L.; ELLIOTT, A.; GROF, C.P.L.; BERDING N.; SMITH, G.R. Developmental and hormonal regulation of direct shoot organogenesis and somatic embryogenesis in sugarcane (Shaccharum spp. interspecific hybrids) leaf culture. Plant Cell Reports, v.25, n.10, p.1007-1015, 2006. https://doi.org/10.1007/s00299-006-0154-1

LEE, T.S.G.; BRESSAN, E.A.; SILVA, A.D.C.; LEE, L.L. Implantação de biofábrica de cana-de-açúcar: riscos e sucessos. Revista Brasileira de Horticultura Ornamental, Campinas, v.16 (suplemento digital), 2007.

LEMOS, E. E. P.; FerReiRA, M. S.; AlenCAR, L. M. C.; NETO, C. E. R.; AlBUQUeRQUE, M. M. Conservação in vitro de germoplasma de cana-de-açúcar. Pesquisa Agropecuaria Brasileira, v.37, n.10, p.1359-1364, 2002. https://doi.org/10.1590/S0100-204X2002001000002

LIMA, G.V.M., Ação de auxinas e cofatores fenólicos no enraizamento in vitro de variedades de cana-de-açúcar (Saccharum officinarum L.). 2010. 96f. (Dissertação mestrado/Programa de PósGraduação Botânica), UFRPE, Recife, 2010.

LIMA, M.A.C.; GARCIA, R.O.; MARTINS, G.S.; MANSUR, E. Morfogênese in vitro e suscetibilidade de calos de variedades nacionais de cana-de-açúcar (Saccharum officinarum L.) a agentes seletivos utilizados em sistemas de transformação genética. Revista Brasileira de Botânica. São Paulo, v.24, n.1, p.73-77, 2001. https://doi.org/10.1590/S0100-84042001000100008 
LORENZO, J.C.; BLANCO, M.A.; PELAEZ, O.; GONZALEZ, A.; CID, M.; IGLESIAS, A.; GONZALEZ, B.; ESCALONA, M.; ESPINOSA, P.; BORROTO, C. Sugarcane micropropagation and phenolic excretion. Plant Cell, Tissue and Organ Culture, v.65, n.1, p.1-8, 2001. https://doi.org/10.1023/A:1010666115337

MAZUR, P. Freezing of living cells: mechanisms and applications. American Journal Physiology, v.247, p.125-142, 1984. https://doi.org/10.1152/ajpcell.1984.247.3.C125

MERYMAN, H.T.; WILLIAMS, R.J.; DOUGLAS, M.S.J. Freezing injury from solution effects and its prevention by natural or artificial cryoprotection. Cryobiology, v.14, p.287-302, 1977. https://doi.org/10.1016/0011-2240(77)90177-8

MUDRY, C.S.; SOUZA, D.K.K.; DIBAX, R.; ALCANTARA, G.B.; FILHO, J.C.B. Embriogênese somática da cultivar RB966928 e do clone RB986419 de cana-de-açúcar (Saccharum spp.). Semina: Ciências Agrárias, v.34, n.3, p.1023-1032, 2013. https://doi.org/10.5433/1679-0359.2013v34n3p1023

MULDREW, K.; ACKER, J.P.; ELLIOT, J.A.W.; MCGANN, L.E. The water to ice transition: implications for living cells. In: FULLER B. J.; LANE N.; BENSON E. E. Life in the frozen state. CRC Press, p.67-108, 2004. https://doi.org/10.1201/9780203647073.ch2

MURASHIGE, T.; SKOOG, F. A revised medium for rapid growth and bioassay with tobacco tissue culture. Physiologia Plantarum, v.15, p.473-479, 1962. https://doi.org/10.1111//.1399$\underline{\text { 3054.1962.tb08052.x }}$

NIINO, T.; SAKAI, A.; YAKUWA, H.; NOJIRI, K. Cryopreservation of in vitrogrown shoot tips of apple and pear by vitrification. Plant Cell, Tissue and Organ Culture, v.28, n.3, p.261-266, 1992. https://doi.org/10.1007/BF00036122

ORTIZ, R.; FÉ, C. de la; GONZÁLEZ, M.T.; ROGRÍGUEZ, A. Estabilidad varietal de la caña de azúcar procedente de meristemos crioconservados. Cultivos Tropicales, v.21, n.2, p.17-19, 2000.

PARMESSUR, Y.; ALJANABI, S.; SAUMTALLY, S.; DOOKUN-SAUMTALLY, A. Sugarcane yellow leaf virus and sugarcane yellows phytoplasma: elimination by tissue culture. Plant Pathology, v.51, p.561-566, 2002. https://doi.org/10.1046/j.1365-3059.2002.00747.x

PAULET, F.; ENGELMANN, F.; GLASZMANN, J.C. Cryopreservation of apices of in vitro plantlets of sugarcane (Saccharum sp. hybrids) using encapsulation/dehydration. Plant Cell Rep, v.12, n.9, p.525-529,1993. https://doi.org/10.1007/BF00236101

REINERT, and J. Untersuchungen über die Morphogenese an Gewebekulturen. Berichte der Deutschen Botanischem Gesellschafy, v.71, p.15, 1959.

RIBEIRO, M.F.; RITTERBUSCH, C.W.; BIANCHI, V.J.; PETERS, J.A. Fontes de carbono na multiplicação in vitro de porta-enxertos de marmeleiro ' $M C^{\prime}$ ' e 'Adams'. Plant Cell Culture \& Micropropagation, v.11, n.2, p.54-61, 2015.

ROBERTS, H.F. Predicting the viability of seeds. Seed Science Technology, v.1, p.499-514, 1973. 
ROSADO, L.D.S.; PINTO, J.E.B.P.; BOTREL, P.P.; BLANK, A.F.; BERTOLUCCI, S.K.V. Aspectos do cultivo in vitro do manjericão cv. maria bonita (Ocimum basilicum L.). In: Plantcellculture e Micropropagation. Plant Cell Culture \& Micropropagation, v.5, n.2, p. 71-144, 2009.

SANTOS, J. da P.; DORNELLES, A.L.C.; PEREIRA, F.D.; OLIVEIRA, L.M. Indução de calos em sempre viva (Syngonanthus mucugensis Giulietti), utilizando diferentes tipos de explantes e concentrações de BAP. Acta Scientiarum Biological Science v.30, n.2, p.127-131, 2008. https://doi.org/10.4025/actascibiolsci.v30i2.3624

SANTOS, T.C. Propagação e conservação in vitro de vetiver (Chrysopogon zizanioides L. Roberty). 2011. 59f. Dissertação (Mestrado em Biotecnologia/ Núcleo em Pós-Graduação em Biotecnologia) -, São Cristóvão, Sergipe. 2011.

SARASAN, V.; CRIPPS R.; RAMSAY M.M.; ATHERTON C.; MCMICHEN M.; PRENDERGAST G.; ROWNTREE J.K. Conservation in vitro of threatened plants - progress in the past decade. In Vitro Cellular \& Developmental Biology - Plant, v.42, n.3, p.206-214, 2006. https://doi.org/10.1079/IVP2006769

SCHMILDT, O.; SCHMILDT, E.R.; AMARAL, J.A.T. Cinetina e ANA na multiplicação in vitro de mamoeiro 'tainung'. Scientia Agrária, v.8, n.1, p.55-60, 2007. https://doi.org/10.5380/rsa.v8i1.8342

SHARP, W.R. et al. Plant cell and tissue culture: principles and applications. Columbus: The Ohio State University, 1979. 892p.

SHIBLI, R.A.; SHATNAWI, M.A.; SUBAIH, W.A.; MOHAMMED, M. A. In vitro conservation and cryopreservation of plant genetic resources: a review. World Journal of Agricultural Sciences, v.2, n.4, p.372-382, 2006.

SNYMAN, S.J.; MEYER, G.M.; RICHARDS, J.M.; HARICHARAN, N.; RAMGAREEB, S.; HUCKETT, B.I. Refining the application of direct embryogenesis in sugarcane: effect of the developmental phase of leaf disc explants and the timing of DNA transfer on transformation efficiency. Plant Cell Reports, v.25, n.10, p.1016-1023, 2006. https://doi.org/10.1007/s00299-006-0148-z

STEWARD, F.C.; MAPES, M.O.; MEARS, K. Growth and organized evelopment of cultured cells. II: organization in cultures grown from freely suspended cells. American Journal of Botany, v.45, n.10, p.705-708, 1958. https://doi.org/10.2307/2439728

TAYLOR, P.W.J.; DUKIC, S. Development of an in vitro culture technique for conservation of Saccharum sp. hybrid germplasm. Plant Cell, Tissue and Organ Culture, v.34, n.2, p.217-222, 1993. https://doi.org/10.1007/BF00036105

TERMIGNONI, R.R. Cultura de Tecidos Vegetais. Porto Alegre, Editora da UFRGS, 2005, 182p.

THORPE, T. History of plant tissue culture. Methods in Molecular Biology, Totowa, v.877, p.9-27, 2012. https://doi.org/10.1007/978-1-61779-818-4 2

TORRES, C.A.; CALDAS, L.S.; BUSO, J.A. Culturas de tecidos e transformação genética de plantas. Brasília, Embrapa - CNPH, v.1, 509p., 1998. 
VENDRUSCOLO, E.P. Cultura de tecidos de plantas no apoio ao melhoramento genético vegetal e à produção massal de plantas. Florianópolis, 2012. 61f.Trabalho conclusão de curso (Agronomia). Universidade Federal de Santa Catarina, Centro de Ciências Agrárias. Florianópolis, 2012.

VILLA, F.; PASQUAL, M.; SILVA, E.F. Micropropagação de híbridos de orquídea em meio knudson com adição de vitaminas do meio MS, benzilaminopurina e carvão ativado. Semina: Ciências Agrárias, v.3, n.2, p.683-694, 2014. https://doi.org/10.5433/1679-0359.2014v35n2p683

WATT, M.P.; BANASIAK, M.; REDDY, D.; ALBERTSE, E.H.; SNYMAN, S. J. In vitro minimal growth storage of Saccharum spp. hybrid (genotype 88H0019) at two stages of direct somatic embryogenic regeneration. Plant Cell Tissue And Organ Culture. v.96, n.3, p.263-271, 2009. https://doi.org/10.1007/s11240-008-9483-9

WITHERS, L.A.; ENGELMANN, F. In vitro conservation of plant genetic resources. In: ALTMAN, A. Biotechnology in agriculture. Marcel Dekker, New York, p. 57-88, 1998. 